\author{
MICHAŁ ROMANOWSKI \\ PIOTR HAIDUK \\ WOJCIECH GRABOWSKI
}

\title{
Bliskie powiązania między agentem ubezpieczeniowym a innymi podmiotami w świetle ustawy z dnia 15 grudnia 2017 r. o dystrybucji ubezpieczeń
}

Zgodnie z nowq ustawq o dystrybucji ubezpieczeń, która stanowi implementację Dyrektywy Parlamentu Europejskiego i Rady (UE) nr 2016/97 w sprawie dystrybucji ubezpieczeń (tzw. IDD), agenci ubezpieczeniowi niebędacy osobami fizycznymi moga wykonywać działalność agencyjnq wyłącznie jeżeli bliskie powiqzania tych agentów nie uniemożliwiaja Komisji Nadzoru Finansowego sprawowania skutecznego nadzoru. W tym kontekście dla praktyki rynku ubezpieczeniowego, a zwłaszcza agentów ubezpieczeniowych oraz podmiotów, które zamierzaja prowadzić działalność agencyjnq, rozumienie pojęcia „,bliskich powiqzań” ma kluczowe znaczenie. Artykuł wskazuje proponowanq wykładnię pojęcia „bliskich powiqzań", a także prezentuje je w świetle funkcjonujqcych powszechnie w życiu gospodarczym grup kapitałowych (holdingów) oraz oddziałów tworzonych przez ubezpieczycieli.

Słowa kluczowe: agenci ubezpieczeniowi, dystrybucja, IDD, bliskie powiązania, KNF, holding oraz oddziały.

\section{Uwagi wprowadzające}

W dniu 1 października 2018 r. weszła w życie ustawa o dystrybucji ubezpieczeń [„u.d.u.”] ${ }^{1}$ implementująca do polskiego porządku prawnego Dyrektywę Parlamentu Europejskiego i Rady (UE) 2016/97 z dnia 20 stycznia 2016 r. w sprawie dystrybucji ubezpieczeń („IDD”). W myśl art. 3 ust. 1 IDD m.in. pośrednicy ubezpieczeniowi rejestrowani są we właściwym organie w państwie członkowskim ich pochodzenia. Regulację art. 3 ust. 1 IDD implementuje art. 52 ust. 1 u.d.u., zgodnie

1. (Dz. U. z 2017 r. poz. 2486 ze zm.) 
z którym agenci ubezpieczeniowi podlegają wpisowi do rejestru pośredników ubezpieczeniowych, który składa się m.in. z rejestru agentów. Rejestr agentów zgodnie z art. 55 ust. 2 u.d.u., implementującym w tym zakresie art. 3 ust. 6 IDD, zawiera w odniesieniu do agentów ubezpieczeniowych niebędących osobami fizycznymi w szczególności tożsamość osób, które mają „bliskie powiązania” z agentem ubezpieczeniowym. Jednocześnie na gruncie art. 19 ust. 4 u.d.u. agent ubezpieczeniowy niebędący osobą fizyczną może wykonywać działalność agencyjną, jeżeli „bliskie powiązania” nie uniemożliwiają Komisji Nadzoru Finansowego [„KNF”] skutecznego sprawowania nadzoru.

W świetle powołanych wyżej przepisów u.d.u. dla praktyki obrotu kluczowe jest udzielenie odpowiedzi na następujące pytania:

1) jakie podmioty moga być traktowane jako osoby, które maja „bliskie powiązania” $z$ agentem ubezpieczeniowym,

2) czy „bliskie powiązania” odnoszą się wyłącznie do bezpośrednich wspólników (akcjonariuszy) agentów ubezpieczeniowych,

3) czy „bliskie powiązania” mogą występować w holdingach oraz

4) jak kształtuja się „bliskie powiązania” wodniesieniu do oddziału utworzonego na terytorium Rzeczpospolitej Polskiej przez ubezpieczyciela.

\section{Cel IDD oraz u.d.u.}

Jednym z podstawowych celów IDD jest zwiększenie poziomu ochrony klientów zawierających umowy ubezpieczenia (pkt 3 oraz pkt 7 preambuły IDD). W szczególności w tym celu IDD ustanawia zasadę, stosownie do której dystrybutorzy ubezpieczeń prowadząc swoją działalność powinni postępować uczciwie, rzetelnie i profesjonalnie oraz zgodnie z najlepiej pojętym interesem ich klientów (art. 17 ust. 1 IDD).

Środkiem służącym do zwiększenia poziomu ochrony klientów jest zapewnienie klientom branży ubezpieczeniowej odpowiednich informacji o pośrednikach działających na rynku ubezpieczeniowym ${ }^{2}$. W tym kontekście postanowienia IDD zmierzają do tego, aby pośrednicy działający na rynku ubezpieczeniowym byli odpowiednio zarejestrowani, a informacje znajdujace się w rejestrze odnośnie każdego pośrednika były łatwo dostępne i mogły być odnalezione bezpośrednio w internecie. Powyższe dążenia wyrażone w IDD potwierdza m.in. art. 52 ust. 4 u.d.u., stosownie do którego „rejestr agentów jest jawny (E)” oraz art. 52 ust. 3 u.d.u., w myśl którego „Rejestr pośredników ubezpieczeniowych jest prowadzony (...) w systemie rejestracji internetowej."

Jednocześnie polski ustawodawca zmierza do rozszerzenia informacji znajdujących się w rejestrze pośredników ubezpieczeniowych. W uzasadnieniu do projektu u.d.u. wskazano, że „Proponuje się także rozszerzenie katalogu danych dostępnych z rejestru przy jednoczesnej zmianie sposobu udostępniania tych danych. Obecnie funkcjonujaca regulacja ustawowa

2. Zob. s. 6 uzasadnienia do u.d.u. (Druk sejmowy nr 1781).

3. Na marginesie należy zauważyć, że pośrednicy ubezpieczeniowi podlegali obowiązkowi rejestracji w poprzednim reżimie prawnym (tj. podczas obowiązywania ustawy z dnia 22 maja 2003 r. o pośrednictwie ubezpieczeniowym], który przewidywał również prowadzenie rejestru przez KNF, przy czym rejestr ten prowadzony był w „systemie informatycznym”. Na podstawie art. 106 ust. 1 u.d.u., rejestr pośredników ubezpieczeniowych prowadzony na podstawie przepisów uprzednio obowiązującej ustawy, staje się rejestrem pośredników ubezpieczeniowym w rozumieniu w Ustawie o Dystrybucji Ubezpieczeń. 
umożliwia organowi nadzoru jedynie udzielanie informacji potwierdzajacych niektóre dane rejestrowe. Zakres tych danych jest obecnie zbyt ograniczony względem potrzeb zgłaszanych przez zainteresowanych."

Zamieszczenie w rejestrze pośredników ubezpieczeniowych informacji o powiązaniach danego agenta z innymi podmiotami należy odczytywać jako zamiar zapewnienia transparentności relacji w obszarze dystrybucji ubezpieczeń - klient nabywający produkty ubezpieczeniowe powinien mieć możliwość dostępu do informacji o powiązaniach (osobowych lub kapitałowych) danego agenta ubezpieczeniowego.

Wymaga podkreślenia, że istnienie „bliskich powiązań” między agentem ubezpieczeniowym a innym podmiotem nie stanowi samo w sobie zjawiska negatywnego. Istnienie „bliskich powiązań” w świetle u.d.u. jest bowiem co do zasady dozwolone. Z niedozwolonymi „bliskimi powiązaniami” na gruncie Ustawy o Dystrybucji Ubezpieczeń będziemy mieli do czynienia dopiero wtedy, gdy organ nadzoru (tu: KNF) stwierdzi, że „bliskie powiązania” istniejące w określonym stanie faktycznym w odniesieniu konkretnych podmiotów uniemożliwiaja KNF sprawowania nadzoru.

Warto odnotować, że odwołanie do „bliskich powiązań” w analogicznym kontekście pojawia się także w ustawie z dnia 11 września 2015 r. o działalności ubezpieczeniowej i reasekuracyjnej („u.d.u.r.") ${ }^{5}$. Przykładowo w świetle art. 170 ust. 1 pkt 11 u.d.u.r. KNF nie może wydać zezwolenia na prowadzenie działalności ubezpieczeniowej, jeżeli „bliskie powiqzania między zakładem ubezpieczeń (...) i innq osoba fizycznq lub prawna stanowiłyby dla organu nadzoru przeszkodę w sprawowaniu nadzoru".

\section{Bliskie powiązania w świetle u.d.u.}

\section{A. Ustawowe pojęcie bliskich powiązań}

U.d.u. definiuje „bliskie powiązania” odwołując się w jej art. 3 ust. 1 pkt 2 do art. 3 ust. 1 pkt 2. u.d.u.r. Stosownie do art. 3 ust. 1 pkt 2 u.d.u.r. „bliskie powiązania” oznaczają sytuację, w której dwa lub więcej podmiotów są ze sobą:

1) powiązane przez udział kapitałowy,

2) powiązane przez kontrolę lub

3) powiązane trwale przez kontrolę z tą samą osoba.

Dla kwalifikacji określonej sytuacji jako „bliskich powiązań” wystarczy stwierdzenie występowania którejkolwiek przesłanki wskazanej powyżej.

\section{B. Powiązanie przez udział kapitałowy}

Stosownie do art. 3 ust. 1 pkt 51 u.d.u.r. „udział kapitałowy” rozumiany jest jako posiadanie, bezpośrednio lub w wyniku powiązania przez kontrolę, co najmniej $20 \%$ praw głosu lub kapitału zakładowego innego podmiotu (co do rozumienia „powiązania przez kontrolę” zob. rozważania poniżej]. W warstwie językowej definicja „udziału kapitałowego” odwołuje się do „20\% kapitału

4. Zob. s. 22 uzasadnienia do Ustawy o Dystrybucji Ubezpieczeń (Druk sejmowy nr 1781).

5. (t.j.:, Dz. U. z 2018 r. poz. 999 ze zm.) 
zakładowego innego podmiotu". Kapitał zakładowy w obecnym stanie prawnym funkcjonuje w spółce z ograniczoną odpowiedzialnością, w spółce akcyjnej oraz w spółce komandytowo-akcyjnej ${ }^{6}$. Oznacza to, że „bliskie powiązania” powstające poprzez „udział kapitałowy” zaistnieja w sytuacji, gdy przykładowo agent ubezpieczeniowy „posiada” akcje stanowiące co najmniej 20\% kapitału zakładowego spółki akcyjnej ewentualnie, gdy agent ubezpieczeniowy jest spółką akcyjna, a co najmniej $20 \%$ w jego kapitale zakładowym posiada inny podmiot (który niekoniecznie musi być spółką kapitałową).

Zauważyć jednak należy, że art 3 ust. 1 pkt 51 u.d.u.r. w swej redakcji językowej odwołuje się także do „posiadania, bezpośrednio (... 20\% praw głosu” nie wskazując jednocześnie w jakiej jednostce organizacyjnej lub w jakim organie prawa głosu maja przysługiwać. Brak dookreślenia w jakiej jednostce organizacyjnej lub w jakim organie ma przysługiwać „20\% praw głosu” może wskazywać na wolę przyjęcia przez ustawodawcę szerokiej formuły co do statusu prawnego podmiotów, między którymi może istnieć powiązanie poprzez „posiadanie, bezpośrednio co najmniej 20\% praw głosu”. Przyjęcie szerokiej formuły oznaczałoby, że „udział kapitałowy” mógłby istnieć przykładowo poprzez „posiadanie, bezpośrednio 20\% praw głosu” w zarządzie lub w radzie nadzorczej spółki kapitałowej albo spółki osobowej (np. w zarządzie spółki partnerskiej). W kontekście powyższych rozważań, wydaje się jednak, że u.d.u.r., a przez to u.d.u. odnosząc się do „posiadania, bezpośrednio 20\% praw głosu" odwołuje się jedynie do organu stanowiącego danej jednostki organizacyjnej. Powyższe twierdzenie wynika z faktu, że nie można mówić o „posiadaniu, bezpośrednim 20\% praw głosu" w zarządzie lub radzie nadzorczej danej jednostki organizacyjnej, bowiem byłoby to sprzeczne z istotą tych organów?. Wpływ na decyzje podejmowane przez zarząd lub radę nadzorczą, które są organami kolegialnymi, wywierać można jedynie poprzez powoływanie lub odwoływanie ich członków.

O zasadności powyższego twierdzenia świadczy okoliczność, że u.d.u. odnosząc się do „udziału kapitałowego" odwołuje się do agentów ubezpieczeniowych będących osobami prawnymi (art. 33 k.c.) albo będących jednostkami organizacyjnymi, które nie są osobami prawnymi, ale którym ustawa przyznaje zdolność prawna (art. $33^{1} \S 1$ k.c.). Gdyby uznać, że „udział kapitałowy” może istnieć poprzez „posiadanie, bezpośrednio (... 20\% praw głosu” w zarządzie albo radzie nadzorczej, literalnie oznaczałoby to, że agent będący osoba prawna „posiada, bezpośrednio (w jakiś sposób] 20\% praw głosu" w zarządzie albo radzie nadzorczej, w skład których w obecnym stanie prawnym moga wchodzić wyłacznie osoby fizyczne (por. 18 § 1 k.s.h.). Nie jest jasne w jaki sposób agent będący osobą prawną miałby „posiadać, bezpośrednio $20 \%$ praw głosu” w zarządzie lub radzie nadzorczej innego podmiotu, a co dopiero w jaki sposób miałby wykonywać te prawo ${ }^{8}$.

Rozróżnienie między „20\% praw głosu” a „20\% kapitału zakładowego” na gruncie u.d.u.r. wynika głównie z faktu, iż w niektórych spółkach kapitałowych mogą istnieć przywileje głosowe, które powoduja, że procentowy udział danego wspólnika w głosach jest wyższy niż procentowy udział kapitałowy. Przykładowo wspólnik spółki z ograniczoną odpowiedzialnością „posiada” 40\%

6. Powyższe rozważania należy rozciągnąć odpowiednio na zagraniczne spółki posiadające kapitał zakładowy (np. niemiecką spółkę akcyjną, ale również spółkę europejską).

7. Zob. M. Romanowski, Prawo o publicznym obrocie papierami wartościowymi. Komentarz, wyd. 2, Warszawa 2003, s. 142.

8. Na marginesie zauważyć należy, że w praktyce obrotu mówi się raczej o „posiadaniu” członków zarządu lub członków rad nadzorczych, co formalnie rzecz ujmując oznacza, że dany członek zarządu lub rady nadzorczej został powołany „dzięki” głosom danego wspólnika. 
udziałów w kapitale zakładowym, które uprawniaja go do wykonywania ponad 50\% ogólnej liczby głosów na zgromadzeniu wspólników. Źródłem różnicy między udziałem w kapitale zakładowym a udziałem w głosach może być również fakt wyemitowania w spółce akcyjnej akcji niemych (tj. akcji bez prawa głosu).

Odnosząc się jeszcze do „posiadania, bezpośrednio 20\% praw głosu” nie można teoretycznie wykluczyć takiego stosunku w odniesieniu do spółki osobowej. Sytuacja taka będzie miała przykładowo miejsce w odniesieniu do walnego zgromadzenia spółki komandytowo-akcyjnej. Powyższa teza odpowiada celowi IDD oraz u.d.u. jakim jest zapewnienie transparentności relacji w obszarze dystrybucji ubezpieczeń. W świetle tego celu, niezasadne wydaje się wykluczenie „z góry” możliwości uznania, że danemu podmiotowi przysługuje „udział kapitałowy” w spółce osobowej jedynie ze względu na posługiwanie się przez ustawodawcę w warstwie językowej sformułowaniem „udział kapitałowy” (które to sformułowanie poprzez użycie słowa „kapitałowy” miałoby odnosić się jedynie do spółek kapitałowych) ${ }^{9}$.

Pojęcie „udział kapitałowy” rozumiane jest również jako „posiadanie (...) w wyniku powiązania przez kontrolę, co najmniej 20\% praw głosu lub kapitału zakładowego innego podmiotu".

\section{Powiązanie przez kontrolę}

Za „powiązanie przez kontrolę” na mocy art. 3 ust. 1 pkt 33 u.d.u.r. rozumie się związek między jednostką dominującą a jednostką zależną lub podobny związek między jakimkolwiek podmiotem a zakładem ubezpieczeń lub zakładem reasekuracji.

Stosownie do art. 3 ust. 1 pkt 15 u.d.u.r. przez jednostkę zależną rozumie się podmiot kontrolowany przez jednostkę dominującą, zaś za jednostkę dominującą zgodnie z art. 3 ust. 1 pkt 14 przywołanej ustawy rozumie się w szczególności podmiot, który sprawuje kontrolę w rozumieniu art. 3 ust. 1 pkt 37 lit. a - d ustawy z dnia 29 września 1994 r. o rachunkowości [ u.o.r.”] ${ }^{10}$, tj.:

1) posiada bezpośrednio lub pośrednio większość ogólnej liczby głosów w organie stanowiącym jednostki zależnej (także na podstawie porozumień z innymi uprawnionymi do głosu, wykonującymi prawa głosu zgodnie z wola jednostki dominującej) (dominacja udziałowa),

2) jest udziałowcem jednostki zależnej i jest uprawniony do kierowania polityką finansową i operacyjną tej jednostki zależnej w sposób samodzielny lub przez wyznaczone przez siebie osoby lub jednostki na podstawie umowy zawartej z innymi uprawnionymi do głosu, posiadającymi na podstawie statutu lub umowy spółki, łącznie z jednostką dominująca, większość ogólnej liczby głosów w organie stanowiącym (dominacja kierownicza),

3) jest udziałowcem jednostki zależnej i jest uprawniony do powoływania i odwoływania większości członków organów zarządzających, nadzorujących lub administrujących tej jednostki zależnej (dominacja osobowa) lub

4) jest udziałowcem jednostki zależnej, której więcej niż połowę składu organów zarządzających, nadzorujących lub administrujących w poprzednim roku obrotowym, w ciagu bieżącego roku obrotowego i do czasu sporządzenia sprawozdania finansowego za bieżący rok obrotowy stanowią osoby powołane do pełnienia tych funkcji w rezultacie wykonywania przez jednostkę

9. W podobny sposób P. Wajda [w:] M. Szczepańska (red.), P. Wajda (red.) Ustawa o działalności ubezpieczeniowej i reasekuracyjnej. Komentarz, komentarz do art. 3 ust. 1 pkt 2, pkt 1, Lex.

10. (t.j.: Dz.U. z 2018 r. poz. 395 ze zm.) 
dominującą prawa głosu w organach tej jednostki zależnej (chyba że inna jednostka lub osoba ma w stosunku do tej jednostki zależnej prawa, o których mowa w pkt 1, 2 lub 3) (dominacja zarządcza).

Ponadto zgodnie z art. 3 ust. 1 pkt 14 u.d.u.r. za jednostkę dominującą może być uznany także inny podmiot, który w ocenie KNF w inny sposób (niż przez sposoby określone w art. 3 ust. 1 pkt 37 lit. a - d u.o.r.] sprawuje kontrolę nad innym podmiotem. Co więcej w świetle art. 3 ust. 1 pkt 33 „powiązanie przez kontrolę” występuje także w sytuacji gdy zakład ubezpieczeń (lub zakład reasekuracji] znajduje się w związku z innym podmiotem, który jest „podobny” do stosunku dominacji.

Cechą wspólną okoliczności, w których dochodzi do powstania stosunku dominacji między jednostką dominującą a jednostką zależna jest sytuacja, w której jednostka dominująca ma możliwość wywierania decydującego wpływu na działalność jednostki zależnej (a więc sprawuje nad nią kontrolę).

Odnosząc się do możliwości uznania przez KNF danej jednostki za jednostkę dominująca, należy zauważyć, że sens powyższego rozwiązania sprowadza się do tego, że KNF (mimo nieistnienia sytuacji określonych w art. 3 ust. 1 pkt 37 lit. a - d u.o.r.) będzie uprawniona do stwierdzenia istnienia stosunku dominacji jeżeli będą przemawiały za tym szczególne okoliczności faktyczne danej sprawy. Mimo pewnego luzu decyzyjnego pozostawionego KNF w tym zakresie, wydaje się, że organ nadzoru nie będzie mógł uznać dowolnie, że określony podmiot jest jednostką dominująca w sytuacji, gdy nie będzie on wywierał decydującego wpływu na inny podmiot (dominacja faktyczna) lub nie będzie posiadał formalnej możliwości wywierania takiego wpływu (dominacja formalna).

Ustawodawca nie określa czym jest związek „podobny” do związku istniejącego między jednostką dominującą a jednostką zależna. Odwołując się jednak do sensu regulacji za trafne należy staną́ stanowisko, stosownie do którego z podobieństwem będziemy mieli do czynienia wówczas, gdy jeden podmiot będzie miał możliwość wywierania decydującego wpływu na drugi podmiot w sposób, który nie został przewidziany w art. 3 ust. 1 pkt 37 lit. a - d u.r.

W świetle u.d.u.r. status prawny jednostki dominującej jest obojętny. Oznacza to, że jednostką dominująca może być osoba fizyczna, osoba prawna jak i jednostka organizacyjna niebędąca osoba prawna, którym ustawa przyznaje zdolność prawną.

Nieco odmienny wniosek należy wyciagnąć w odniesieniu do statusu prawnego jednostki zależnej. Po pierwsze, z oczywistych względów należy wykluczyć możliwość istnienia stosunku dominacji wobec osoby fizycznej (osoba fizyczna może być jednostką dominująca, natomiast nie może być jednostką zależna]. Po drugie, nie wszystkie jednostki organizacyjne niebędące osobami prawnymi, którym ustawa przyznaje zdolność prawna posiadają organy, do których odwołuje się u.o.r. stanowiąc o dominacji osobowej oraz o dominacji zarządczej (co do dominacji udziałowej zob. rozważania poniżej). Wynika to z okoliczności, że o ile osoby prawne działaja przez swoje organy (art. 38 k.c.), o tyle jednostki organizacyjne, o których mowa wart. $33^{1} \S 1$ k.c. działaja zasadniczo poprzez swoich przedstawicieli ustawowych. Nie wyklucza to jednak możliwości ustanowienia w niektórych jednostkach organizacyjnych „stanowisk”, którym przyznać można status organu. Przykładem takiej sytuacji będzie zarząd w spółce partnerskiej. Istnieja oczywiście poglady utożsamiające organy wyłacznie z osobami prawnymi (a przez to wykluczające możliwość funkcjonowania organów w jednostkach organizacyjnych niebędących osobami prawnymi, którym ustawa przyznaje zdolność prawna). Biorąc jednak pod uwagę zasadę pierwszeństwa rzeczywistej treści na forma (substance over form) wyrażoną chociażby w art. 4 ust. 2 u.o.r. („Zdarzenia, w tym operacje gospodarcze, ujmuje się (E) 
zgodnie z ich treściq ekonomicznq"] oraz cel IDD oraz u.d.u. [tj. zapewnienie transparentność), należy uznać możliwość potraktowania niektórych jednostek organizacyjnych, o których mowa w art. $33^{1} \S$ k.c. za jednostkę zależną.

Rozpatrując jeszcze kwestię dominacji osobowej oraz dominacji zarządczej, które odnoszą się do organów zarządzających, nadzorujacych lub administrujących danych jednostek organizacyjnych, należy uznać, że de lege lata chodzi tutaj w istocie rzeczy o zarzạdy lub rady nadzorcze spółek kapitałowych (niekiedy spółek osobowych). Nie można natomiast uznać przykładowo, że organem zarządzającym danego podmiotu będzie prokurent (tj. pełnomocnik „Szczególnego" rodzaju) lub osoba pełniąca funkcję dyrektora oddziału danego przedsiębiorcy (w odniesieniu do oddziału zob. rozważania poniżej).

Odnosząc się jeszcze do dominacji udziałowej warto zauważyć, że u.o.r. odwołuje się w tym zakresie do ogólnej liczby głosów w organie stanowiącym jednostki zależnej. Za organ stanowiący w tym kontekście należy uznać przykładowo zgromadzenie wspólników spółki z ograniczona odpowiedzialnością. Za ogólną liczbę głosów należy uznać natomiast sumę głosów przypadającą na wszystkie akcje lub udziały danej spółki. Oznacza to, że w ramach ogólnej liczby głosów winno uwzględniać się wszystkie głosy, które mogą istnieć w danej spółce, przy czym bez znaczenia jest to czy są one faktycznie wykonywane ${ }^{11}$.

Poprzez wyraźne odwołanie się do „pośredniego” posiadania większości ogólnej liczby głosów w przypadku dominacji udziałowej u.o.r. jednoznacznie określa, że przedmiotem regulacji jest zarówno dominacja jednostopniowa (bezpośrednia) oraz dominacja wielostopniowa (pośrednia). Zatem badając stosunek dominacji nie należy ograniczać się wyłącznie do relacji między dwoma podmiotami. Wielostopniowość dominacji polega na tym, że jednostka zależna od jednostki dominującej (wyższego stopnia) jest równocześnie jednostką dominującą (niższego stopnia) dla jednostek zależnych, w których posiada większość ogólnej liczby głosów. Niezależnie od ilości stopni w strukturze grupy kapitałowej, jednostka kontrolowana określana jest jako jednostka zależna, chociaż w strukturze danej grupy kapitałowej może być także jednostką dominującą dla spółek znajdujących się na niższym stopniu grupy. Spółka dominująca wyższego szczebla w tak ukształtowanej strukturze nie musi posiadać bezpośrednio udziałów w spółkach zależnych niższego stopnia, bowiem sprawuje kontrolę nad tymi spółkami za pośrednictwem swojej spółki zależnej, która jest równocześnie spółką dominującą (niższego stopnia) w stosunku do innych spółek.

\section{Powiązanie trwale przez kontrolę $z$ tą samą osobą}

Ostatnia przesłanką, która może decydować o istnieniu „bliskich powiązań” w świetle u.d.u. jest, zgodnie z art. 3 ust. 1 pkt 2 u.d.u.r., sytuacja, w której dwa lub więcej podmiotów są ze sobą

11. Por. art. 4 pkt 17 ustawy z 29 lipca 2005 r. o ofercie publicznej i warunkach wprowadzania instrumentów finansowych do zorganizowanego systemu obrotu oraz o spółkach publicznych, zgodnie z którym przez ogólna liczbę głosów rozumie się sumę głosów przypadających na wszystkie akcje spółki. Jednocześnie zauważyć należy, że Ustawa o Rachunkowości określa sposób liczenia głosów lub praw dotyczących powoływania lub odwoływania organów spółek zależnych, gdy te rozstrzygają o sprawowaniu kontroli. Przykładowo w myśl ust. $1 \mathrm{f} \mathrm{i} 1 \mathrm{~g}$ art. 3 Ustawy o Rachunkowości prawa głosu oraz prawa powoływania i odwoływania członków organów zarządzających, nadzorujących lub administrujących należące do dowolnej innej jednostki zależnej, a także prawa należące do osób działających w imieniu własnym, ale na rzecz jednostki dominującej lub innej jednostki zależnej są sumowane z odpowiednimi prawami jednostki dominującej. 
powiązane „trwale” przez kontrolę z tą samą osobą. Powyższy stan faktyczny odnosi się do sytuacji, gdy co najmniej dwie jednostki zależne kontrolowane są w sposób określony w art. 3 ust. 1 pkt 37 lit. a - d u.o.r. przez jeden i ten sam podmiot dominujacy, przy czym dominacja ta ma charakter na tyle „trwały”, że uzasadnia uznanie, że między dwoma jednostkami zależnymi istnieja „bliskie powiązania”.

Sens powyższego uregulowania sprowadza się do tego, że „trwałość” powiązań między co do zasady autonomicznymi podmiotami powoduje, że podmioty te w naturalny sposób posiadają zbieżne interesy, które są łącznie realizowane. Wyróżnienie tego jednego zbieżnego interesu, odrębnego od własnego interesu danej jednostki organizacyjne, pozwala postawić tezę, że między takimi podmiotami istnieje „trwałe” powiązanie przez kontrolę. Sytuacja taka będzie miała miejsce w szczególności w odniesieniu do spółek sióstr funkcjonujących w ramach grup kapitałowych.

Od „trwałych” powiązań należy w szczególności odróżnić powiązania o charakterze „tymczasowym” lub „doraźnym”. Chodzi tu o sytuacje, gdy między dwoma podmiotami zależnymi powstanie powiązanie w wyniku przejęcia nad nimi kontroli przez podmiot dominujący, jednak powiązanie to będzie wyłącznie chwilowe. Przykładem takiej sytuacji będzie nabycie przez fundusz inwestycyjny pakietu kontrolnego w dwóch niezwiązanych ze sobą spółkach wyłącznie w celach spekulacyjnych ${ }^{12}$.

\section{Bliskie powiazania w holdingach}

Holding oznacza zasadniczo powiązanie występujące między co najmniej dwoma autonomicznymi w sensie prawnym podmiotami prowadzacce do uzyskania przez jeden z tych podmiotów dominacji nad działalnością drugiego podmiotu. Z tego względu, że ten drugi podmiot (podmiot zależny) realizuje strategię oraz interesy gospodarcze pierwszego podmiotu (podmiotu dominujacego) w systemie prawnym przyjmuje się w określonych przypadkach fikcje, że podmioty te stanowia jeden organizm gospodarczy realizujacy swoje własne interesy.

Cechą konstytutywną holdingów jest występujące między jej członkami powiązania o charakterze pionowym, które odróżniają holding od innych struktur horyzontalnych (przykładowo od konsorcjów). Powiązania w holdingu mogą mieć charakter wielostopniowy. W ramach holdingu pionowego mogą istnieć również relacje horyzontalne, tj. między tzw. spółkami siostrami, które kontrolowane sa przez ten same podmiot, przy czym podstawą istnienia tych relacji jest istnienie uprzedniej relacji pionowej (stosunku dominacji). Istnienie holdingu wymaga istnienia powiązania o charakterze kapitałowym lub obligacyjnym, które to powiązanie prowadzi do powstania określonych zależności pozwalając jednemu z podmiotów wywierać wpływ na działalność drugiego podmiotu, który to podmiot normatywnie jest podmiotem autonomicznym.

Przedstawione powyżej cechy holdingu wskazuja, że „bliskie powiązania”, o których mowa w art. 3 ust. 1 pkt 3 u.d.u. będą istniały zwłaszcza w holdingach. Wynika to z faktu, że istota holdingu oraz „bliskich powiązań” wyraża się właśnie w istnieniu relacji pionowej (dominacji) między normatywnie samodzielnymi podmiotami. Biorąc jednak pod uwagę, że „bliskie powiązania” istnieją także w przypadku istnienia powiązania przez „udział kapitałowy” ( tj. „posiadania” co najmniej 20\% praw głosów lub kapitału zakładowego) uznać należy, że „bliskie powiązania” w świetle u.d.u.

12. Podobny przykład w odniesieniu do grup kapitałowych podaje A. Szumański [w:] S. Sołtysiński (red.) Prawo spółek kapitałowych. System Prawa Prywatnego t. 17A, wyd. 2, Warszawa 2015, s. 793. 
moga istnieć także poza holdingami. Wynika to z okoliczności, że „posiadanie” przez jeden podmiot 20\% praw głosu (lub kapitału zakładowego) w drugim podmiocie nie oznacza jeszcze, że między tymi podmiotami istnieje relacja holdingowa (relacja dominacji).

\section{Bliskie powiązania w oddziałach}

Ubezpieczyciel może prowadzić na terenie Rzeczpospolitej Polskiej działalność w formie oddziału. Zgodnie z art. 3 ust. 1 pkt 22 u.d.u.r. za oddział rozumie się każdą formę stałej obecności na terytorium Rzeczypospolitej Polskiej ubezpieczyciela, w tym oddział, w rozumieniu ustawy z dnia 6 marca 2018 r. o zasadach uczestnictwa przedsiębiorców zagranicznych i innych osób zagranicznych w obrocie gospodarczym na terytorium Rzeczypospolitej Polskiej ["u.z.p.z”] ${ }^{13}$.

W świetle art. 3 pkt 4 u.z.p.z. oddział oznacza wyodrębnioną i samodzielną organizacyjnie część działalności gospodarczej, wykonywana przez przedsiębiorcę poza siedzibą przedsiębiorcy lub głównym miejscem wykonywania działalności ${ }^{14}$.

Mimo wyodrębnienia i samodzielnego organizacyjnie charakteru oddziału, jednostka organizacyjna jakajest oddział na gruncie polskiego prawa nie dysponuje samodzielna podmiotowościa prawną w stosunkach cywilnoprawnych. Brak samodzielnej podmiotowości oddziału powoduje, że nie można uznać formalnoprawnej odrębność oddziału od przedsiębiorcy. Oddział utworzony przez przedsiębiorcę stanowi część tego przedsiębiorcy i „korzysta” z jego formalnoprawnej podmiotowości. Oddział funkcjonuje w obrocie w ramach podmiotowości prawnej przedsiębiorcy zagranicznego i bez tej podmiotowości nie może istnieć. Biorąc pod uwagę powyższą zależność, wszelkie czynności prawne „dokonywane” przez oddział stanowią w istocie czynności podejmowane przez samego przedsiębiorcę zagranicznego i to w odniesieniu do tego przedsiębiorcy powstaja skutki prawne. Powyższy pogląd potwierdza jednoznacznie orzecznictwo, bowiem jak trafnie stwierdził w jednym ze swych orzeczeń Sąd Najwyższy: „Należy przy tym pamiętać, że status przedsiębiorcy posiada wyłącznie ten podmiot, który utworzył oddział na użytek prowadzonej przez siebie działalności gospodarczej. Działalność prowadzona przez oddział ma w zasadzie charakter zależny i powoduje bezpośrednie powstawanie praw i obowiqzków po stronie przedsiębiorcy. ${ }^{15 "}$

Odnosząc się do zagadnienia istnienia „bliskich powiązań” w oddziałach, należy uznać, że ze względu na fakt, że oddział jest w rzeczywistości wewnętrzną jednostką organizacyjną określonego przedsiębiorcy, to między zarządem lub radą nadzorczą ubezpieczyciela, który utworzył oddział a oddziałem tym nie istnieją „bliskie powiązania”, o których mowa u.d.u. Powyższa teza wynika z faktu, że zgodnie z u.d.u. (u.d.u.r.) „bliskie powiązania” istnieją między co najmniej dwoma podmiotami, które powiązane są w określony sposób, zaś ubezpieczyciel, który utworzył oddział i ten oddział są w sensie formalnoprawnym jednym (tym samym) podmiotem. W tym

13. (Dz. U. z 2018 r. poz. 649 ze zm.)

14. Tożsama definicja oddziału znajdowała się w nieobowiązującej już ustawie z 2 lipca 2004 r. o swobodzie działalności gospodarczej.

15. Zob. wyrok Sądu Najwyższego z dnia 16 lutego 2017 r. (sygn. UK 725/15), Lex nr 2252206. Cytowany wyrok został wydany na gruncie ustawy z dnia 2 lipca 2004 r. o swobodzie działalności gospodarczej, zachowuje on jednak aktualność w odniesieniu do Ustawy o Zasadach Uczestnictwa Przedsiębiorców Zagranicznych. 
kontekście nie ma w rzeczywistości różnicy między oddziałem (wyodrębnioną jednostką organizacyjną) a departamentem danego przedsiębiorcy (niewyodrębniona jednostką organizacyjna).

W odniesieniu do przypadku, gdy „udział kapitałowy” w agencie ubezpieczeniowym „posiada” oddział utworzony przez ubezpieczyciela, „bliskie powiązania” w rozumieniu u.d.u. będą istniały między agentem ubezpieczeniowy a ubezpieczycielem (a nie oddziałem utworzonym przez ubezpieczyciela). Wynika to z faktu, że „posiadanie” „udziału kapitałowego” przez oddział polega formalnoprawnie na „posiadaniu” tego udziału przez podmiot, który utworzył oddział (tj. ubezpieczyciel). Należy przy tym zastrzec, że sformułowanie „udział kapitałowy” w agencie „posiada” oddział jest uproszczeniem uzasadnionym jasnością analizy, gdyż od strony formalnej (cywilistycznej) taka sytuacja nie występuje.

\section{Podsumowanie}

U.d.u. definiuje „bliskie powiązania” odwołując się do u.d.u.r., zgodnie z którą „bliskie powiązania” oznaczaja sytuację, w której dwa lub więcej podmiotów są ze sobą:

1) powiązane przez udział kapitałowy,

2) powiązane przez kontrolę lub

3) powiązane trwale przez kontrolę z tą samą osobą.

„Udziałkapitałowy” w świetle u.d.u.r.jest rozumiany jako posiadanie, bezpośrednio lub w wyniku powiązania przez kontrolę, co najmniej $20 \%$ praw głosu lub kapitału zakładowego innego podmiotu. „Bliskie powiązania” powstające poprzez „udział kapitałowy” zaistnieja przede wszystkim w sytuacji, gdy agent ubezpieczeniowy „posiada” co najmniej 20\% kapitału zakładowego lub co najmniej 20\% praw głosu w ogranie stanowiącym danej jednostki lub, gdy co najmniej $20 \%$ w kapitale zakładowym lub co najmniej 20\% praw głosu w organie stanowiącym agenta ubezpieczeniowego posiada inny podmiot. Należy wyrazić stanowisko, że u.d.u.r. (a przez to u.d.u.) odnosząc się do „posiadania, bezpośrednio 20\% praw głosu" odwołuje się jedynie do organu stanowiącego danej jednostki organizacyjnej (tym samym „udział kapitałowy” nie zaistnieje w sytuacji posiadania 20\% praw głosu w zarządzie lub radzie nadzorczej danego podmiotu).

Za „powiązanie przez kontrolę” na mocy art. 3 ust. 1 pkt 33 u.d.u.r. rozumie się związek między jednostką dominującą a jednostką zależna ( lub podobny związek między jakimkolwiek podmiotem a zakładem ubezpieczeń lub zakładem reasekuracji). Za jednostkę dominująca, zgodnie z u.d.u.r., uznaje się podmiot, który sprawuje kontrolę w rozumieniu art. 3 ust. 1 pkt 37 lit. a - d u.o.r. nad innym podmiotem (jednostką zależna) lub inny podmiot, który w ocenie KNF w inny sposób sprawuje kontrolę nad innym podmiotem. Za sprawowanie kontroli, o której mowa w art. 3 ust. 1 pkt 37 lit. a - d u.o.r. uznaje się dominację udziałową, dominację kierowniczą, dominację osobową oraz dominację zarządczą.

Dominacja udziałowa polega na wywieraniu wpływu (pośrednio lub bezpośrednio) na działalność danej jednostki poprzez kontrolę jej organu stanowiącego. Dominacja osobowa oraz dominacja zarządcza polegają z kolei na sprawowaniu kontroli przede wszystkim nad zarządem lub radą nadzorczą innego podmiotu (jednostki zależnej), przy jednoczesnym posiadaniu udziału w takiej jednostce. Dominacja kierownicza wyraża się w kierowaniu polityką finansową i operacyjną innego podmiotu (jednostki zależnej), przy jednoczesnym posiadaniu w nim udziału. 
Trwałe „powiązania przez kontrolę” z tą samą osobą odnoszą się do sytuacji, gdy co najmniej dwie jednostki zależne kontrolowane są w określony sposób przez jeden i ten sam podmiot dominujący, przy czym dominacja ta ma charakter na tyle „trwały”, że uzasadnia uznanie, że między tymi jednostkami zależnymi istnieją „bliskie powiązania”.

W powyższym kontekście, tytułem przykładu, za osobę „blisko powiązana” z danym podmiotem nie powinno uznawać się członka zarządu lub rady nadzorczej danego podmiotu, chyba że osoba taka posiada „udział kapitałowy” w danym podmiocie lub jest wobec niego jednostką dominujacym w sposób opisany powyżej.

Biorąc pod uwagę powyższe konkluzje należy stwierdzić, że „bliskie powiązania” mogą istnieć również między agentem ubezpieczeniowym a jego „pośrednimi” wspólnikami.

Poprzez wyraźne odwołanie się do „pośredniego” posiadania większości ogólnej liczby głosów w przypadku dominacji udziałowej, o której mowa w u.o.r. (do której odsyła u.d.u.r.) należy stwierdzić, że przedmiotem regulacji „bliskich powiązań” na gruncie u.d.u. jest zarówno dominacja jednostopniowa (bezpośrednia) oraz dominacja wielostopniowa (pośrednia). Oznacza to, że badając stosunek dominacji oraz „bliskich powiązań” nie należy ograniczać się wyłącznie do relacji między „bezpośrednimi” wspólnikami danego podmiotu.

Powyższe oznacza, że „bliskie powiązania” mogạ istnieć w holdingach. Wynika to bowiem z okoliczności, że zasadniczą cechą holdingów jest istnienie dominacji między różnymi autonomicznymi podmiotami. Biorąc jednak pod uwagę, że „bliskie powiązania” istnieją także w przypadku powiązania przez „udział kapitałowy” (tj. „posiadanie” co najmniej 20\% praw głosu lub kapitału zakładowego) uznać należy, że „bliskie powiązania” w świetle u.d.u. mogą istnieć nie tylko w strukturach holdingowych.

Odnosząc się do jednostek mających „bliskie powiązania” z oddziałami utworzonymi przez zakładu ubezpieczeń należy zauważyć, że jednostkami tymi w szczególności mogą być jednostki dominujace wobec zakładu ubezpieczeń lub jednostki zależne od zakładu ubezpieczeń, ale również podmioty, które posiadaja „udział kapitałowy” w zakładzie ubezpieczeń lub, w których zakład ubezpieczeń posiada „udział kapitałowy”.

Wskazane konkluzje wynikają z faktu, że jednostka organizacyjna jakajjest oddziałna gruncie polskiego prawa nie dysponuje samodzielną podmiotowością prawną w stosunkach cywilnoprawnych. Oddział utworzony przez przedsiębiorcę stanowi część tego przedsiębiorcy i „korzysta” z jego formalnoprawnej podmiotowości. Tym samym, oddział (sam w sobie) nie może być ani jednostką zależną ani dominująca albo posiadać „udział kapitałowy” w innym podmiocie (lub inny podmiot nie może posiadać „udziału kapitałowego” w oddziale). Między zarządem lub rada nadzorczą ubezpieczyciela, który utworzył oddział a tym oddziałem nie istnieją „bliskie powiązania”, bowiem w sensie formalnoprawnym jest to ten sam podmiot. Natomiast gdy „udział kapitałowy” w agencie ubezpieczeniowym „posiada” oddział utworzony przez ubezpieczyciela, „, bliskie powiązania” w rozumieniu Ustawy o Dystrybucji Ubezpieczeń będą istniały między tym agentem ubezpieczeniowy a ubezpieczycielem (a nie między agentem a oddziałem utworzonym przez ubezpieczyciela). 


\section{Wykaz źródeł:}

M. Romanowski, Prawo o publicznym obrocie papierami wartościowymi. Komentarz, wyd. 2, Warszawa 2003,

S. Sołtysiński (red.) Prawo spółek kapitałowych. System Prawa Prywatnego t. 17A, wyd. 2, Warszawa 2015,

M. Szczepańska (red.), P. Wajda (red.) Ustawa o działalności ubezpieczeniowej i reasekuracyjnej, Warszawa 2016.

\section{Close links between insurance intermediaries [agents] and other entities in the light of the act of 15 December 2017 on insurance distribution}

According to the new Insurance Distribution Act which implements Directive [EU] 2016/97 on insurance distribution (IDD) insurance intermediaries that are not natural persons may perform agency activities only if the close links of such intermediaries do not prevent Polish Financial Supervision Authority to exercise effective supervision. In this context for insurance market in particular, for insurance intermediaries and entities that intend to run agency activities, it is crucial to understand the notion of "close links". The article indicates the proposed interpretation of "close links" and presents it connection with capital groups (holdings) and branches established by insurers, i.e. entities commonly functioning in economic life.

Key words: insurance intermediaries, distribution, IDD, close links, KNF, holdings and branches.

PROF. DR HAB. MICHAŁ ROMANOWSKI - Uniwersytet Warszawski, e-mail:m.romanowski@wpia.uw.edu.pl

PIOTR HAIDUK - adwokat i partner w kancelarii Romanowski i Wspólnicy, e-mail: p.haiduk@romanowski.eu

WOJCIECH GRABOWSKI - apl. adw. i prawnik w kancelarii Romanowski i Wspólnicy, e-mail:w.grabowski@romanowski.eu 